\title{
ANALISIS TEKANAN PENDUDUK TERHADAP LAHAN PERTANIAN DI KECAMATAN BULELENG
}

\author{
Ni Nyoman Tri Mahayani, Ida Bagus Made Astawa, Dewa Made Atmaja \\ Jurusan Pendidikan Geografi \\ Universitas Pendidikan Ganesha \\ Singaraja, Indonesia
}

email: trimahayani55@gmail.com, idabagusmadeastawa@yahoo.com, atmajadewamade@yahoo.com

\begin{abstract}
Abstrak
Penelitian ini dilaksanakan di Kecamatan Buleleng, dengan tujuan untuk, (1) menganalisis tekanan penduduk terhadap lahan di Kecamatan Buleleng, dan (2) menganalisis daya dukung lahan di Kecamatan Buleleng. Penelitian dirancang sebagai penelitian deskriptif, dengan studi populasi secara agregat. Objek dalam penelitian ini adalah tekanan penduduk terhadap lahan pertanian dan daya dukung lahan di Kecamatan Buleleng, dengan subjek penelitian lahan pertanian dan penduduk disetiap desa/kelurahan di Kecamatan Buleleng secara agregat. Data dikumpulkan dengan lembar pencatatan dokumen dan dianalisis secara deskriptif-kualitatif. Hasil penelitian menunjukkan bawah (1) secara umum tekanan penduduk terhadap lahan pertanian belum dialami oleh sebagaian besar desa/kelurahan di Kecamatan Buleleng, kecuali di Desa Banyuning, Penglatan dan Tukad Mungga. (2) Daya dukung lahan pertanian di Kecamatan Buleleng secara keseluruhan tidak mampu swasembada pangan, kecuali desa/kelurahan Jineng Dalem, Petandakan, Sari Mekar, Alas Sangker, dan Poh Bergong. Penelitian ini secara teoritis dapat memberikan kontribusi empiris bagi ilmu Geografi Penduduk dan dapat dijadikan rujukan bagi peneliti lain, khususnya dalam menganalisis tekanan penduduk terhadap lahan pertanian. Berkenaan dengan hasil yang telah ditemukan maka saran dalam penelitian ini yaitu masyarakat sebagai pengelola lahan pertanian mampu menekan laju pertumbuhan penduduk dengan cara melaksanakan program $K B$, menunda usia kawin, serta meningkatkan pendidikan dan melakukan diversifikasi kegiatan ekonomi di luar pertanian, sehingga masyarakat tidak terlalu bergantung pada lahan pertanian.
\end{abstract}

Kata Kunci: Tekanan penduduk, Daya dukung lahan, Produktivitas pertanian

\begin{abstract}
Abstrak
This research was conducted in Buleleng district, this study aims to (1) analyzing population pressure on the land in Buleleng sub-district, and (2) analyzing the carrying capacity of the land in Buleleng district. The study was designed as a descriptive study, with population studies using research subjects in aggregate. Objects in this study were population pressure on agricultural land and land carrying capacity in Buleleng Subdistrict, with research subject of agricultural land and population in every village / kelurahan in Buleleng Subdistrict in aggregate. Data were collected with document recording sheets and analyzed descriptively-qualitative. The results showed that (1) in general the population pressure on agricultural land has not been experienced by most villages in Buleleng sub-district except in Banyuning, Penglatan and Tukad Mungga villages. (2) The carrying capacity of agricultural land in Buleleng sub-district as a whole is not capable of food self-sufficiency, except for the villages of Jineng Dalem, Petandakan, Sari Mekar, Alas Sangker, and Poh Bergong. With regard to the results that have
\end{abstract}


been found, the recomendation in this study is that the community as the manager of agricultural land is able to suppress the population growth rate by implementing the family planning program, delaying the marriage age, as well as improving the education and diversifying the economic activities outside agriculture, agricultural land

\section{Keywords: Population pressure, The carrying capacity of land, Agricultural produkctivitas}

\section{PENDAHULUAN}

Pertumbuhan penduduk di suatu daerah akan mempengaruhi persediaan bahan makanan dan tempat tinggal. Laju pertumbuhan bahan makanan jauh lebih lambat dibandingkan dengan laju pertumbuhan penduduk, apabila tidak dilakukan pembatasan pertumbuhan penduduk maka manusia akan mengalami kekurangan bahan makanan (Malthus, 1798 dalam Mantra 2003:52). Peningkatan jumlah penduduk sangat berkaitan dengan peningkatan kebutuhan terhadap lahan, sehingga dapat menyebabkan terjadinya konversi lahan pertanian ke lahan non pertanian. Konversi lahan tersebut berdampak pada perubahan ekologis yang mengarah ke degradasi lingkungan (Sartohadi, 2008:11).

Kabupaten Buleleng merupakan kabupaten yang terletak di Bali Utara, dilihat dari segi persebaran penduduk wilayah yang paling banyak penduduknya adalah Kecamatan Buleleng (20,86 \%), dan Kecamatan Busungbiu merupakan daerah yang paling sedikit penduduknya (6,2\%) (BPS Kabupaten Buleleng, 2016). Dominannya penduduk berada di Kecamatan Buleleng disebabkan karena Kecamatan Buleleng merupakan pusat pemerintahan, perekonomian, pendidikan, sosial, budaya dan lain-lainnya. Kondisi tersebut juga menyebabkan wilayah Kecamatan Buleleng menjadi daerah yang terpadat penduduknya, yaitu 3.074 jiwa $/ \mathrm{km} 2$. Berdasarkan data Badan Pusat Statistik, Kabupaten Buleleng mengalami peningkatan jumlah penduduk dari tahun 2010 sampai tahun 2015. Pada Tahun 2010 jumlah penduduk Kecamatan Buleleng 120.239 jiwa pada tahun 2016 mencapai 134.810 jiwa (BPS, 2016).

Kecamatan Buleleng merupakan sebuah kecamatan di Bali yang menjadi tempat berdirinya salah satu universitas ternama di Bali yaitu Universitas Pendidikan Ganesha. Universitas tersebut sangat mendukung Kota Singaraja sebagai kota pendidikan. Pada awalnya universitas tersebut hanya berstatus institut namun sejak 2006 sudah berstatus universitas. Perubahan tersebut menyebabkan Universitas Pendidikan Ganesha semakin dikenal secara nasional, ini merupakan salah satu pendorong peningkatan perekonomian di Kecamatan Buleleng. Peningkatan perekonomian inilah salah satu yang dinilai juga menjadi penyebab semakin banyak migran yang menetap di Kecamatan Buleleng.

Meningkatnya jumlah penduduk di Kecamatan Buleleng menyebabkan kebutuhan akan lahan juga semakin meningkat. Alih fungsi lahan dari lahan pertanian untuk memenuhi kebutuhan hidup penduduk tidak dapat dihindarkan. Konversi lahan yang meluas jika tidak dikendalikan akan mempengaruhi jumlah produksi padi. Meluasnya konversi lahan menjadi penyebab utama para petani meninggalkan sawahnya.Hal itu diperparah dengan tidak dilaksanakannya reforma agraria. Setiap hari diperkirakan sekitar lima ribu petani meninggalkan profesinya. Petani memilih pergi ke kota dan terpaksa menjadi kuli, buruh migran atau sektor informal yang lain. Hal tersebut menyebabkan jumlah petani yang ada di Indonesia terus berkurang (Suratha, 2015:69)

Kenyataan kawasan pertanian di Kecamatan Buleleng akhir-akhir ini semakin tersedak oleh berdirinya permukiman serta bangunan lainnya. Keadaan ini mengakibatkan meningkarnya tekanan penduduk terhadap lahan pertanian. Dengan kata lain kebutuhan akan lahan garapa terus bertambah sementara luas lahan relative tetap bahkan juga dimanfaatkan untuk permukiman.

Semakin besar persentase lahan yang dapat dipergunakan untuk pertanian, maka makin kecil tekanan pada wilayah tersebut, dengan kata lain daya dukung lingkungan masih besar. Selain masalah 
penduduk atas lahan yang makin tinggi, perlu diperhatikan juga masalah daya dukung lahan pertanian dan lingkungan. Hal ini berkaitan dengan masalah penyediaan, atau swasembada pangan khususnya beras.

Penelitian ini bertujuan untuk (1) menganalisis tekanan penduduk terhadap lahan pertanian di Kecamatan Buleleng, (2) menganalisis daya dukung lahan di Kecamatan Buleleng.

\section{METODE}

Penelitian ini dilakukan di Kecamatan Buleleng. Objek dalam penelitian ini adalah tekanan penduduk terhadap lahan pertanian dan daya dukung lahan pertanian di Kecamatan Buleleng. Berkenaan dengan itu yang dijadikan subjek penelitian adalah penduduk di setiap desa di Kecamatan Buleleng dan lahan pertanian di Kecamatan Buleleng. Berdasarkan subjek penelitian, maka generalisasi yang akan dilakukan adalah berkaitan dengan subjek tersebut, sehingga populasi dalam penelitian ini adalah subjek itu sendiri. Penelitian ini tidak menggunakan sampel, seluruh populasi digunakan untuk diteliti secara agregat atau disebut dengan studi populasi. Penentuan sampel ini digunakan karena anggota populasinya relatif kecil yaitu kurang dari 30 . Rancangan penelitian dalam penelitian ini adalah penelitian deskriptif. Data yang digunakan adalah data sekunder yang didapat dari BPS (Badan Pusat Statistik) dan Dinas Pertanian. Data yang sudah didapt kemudian dianalisis dengan menggunakan analisis deskriftif-kualitatif yaitu penelitian yang diarah untuk mendeskripsikan gejala-gejala, fakta-fakta atau kejadian-kejadian secara sistematis dan akurat mengenai sifat popuasi daerah tertentu. Gejala atau kejadian yang akan dideskripsikan dalam penelitian ini adalah analisis tekanan penduduk dan daya dukung lahan di Kecamatan Buleleng. Pendeketan yang digunakan adalah pendekatan Keruangan.

\section{HASIL DAN PEMBAHASAN \\ Tekanan Penduduk Terhadap Lahan Pertanian Di Kecamatan Buleleng}

Penentuan tekanan penduduk terhadap lahan pertanian menurut (Otto Soemarwoto(1985, dalam Mantra 2003) berdasarkan Model I ditentukan oleh beberapa variable yaitu: luas lahan yang diperlukan untuk hidup layak (ha/petani), jumlah petani, laju pertmbuhan penduduk, dan luas lahan pertanian. Berdasarkan variabel tersebut makan dapat diketahui nilai tekanan penduduk terhadap lahan di Kecamatan Buleleng sebagai berikut:

Tabel 1. Katagori Tekanan Penduduk Terhadap Lahan Pertanian Di Kecamatan Buleleng

\begin{tabular}{|c|c|c|c|}
\hline No & Desa/Kelurahan & $\overline{T P}$ & Katagori \\
\hline$\overline{(1)}$ & (2) & (3) & (4) \\
\hline 1 & Kalibukbuk & 0,68 & $\mathrm{TP}<1$ \\
\hline 2 & Anturan & 0,51 & TP $<1$ \\
\hline 3 & Tukad Mungga & 1,24 & $\mathrm{TP}>1$ \\
\hline 4 & Pemaron & 0,01 & TP $<1$ \\
\hline 5 & Bakti Seraga & 0,28 & $\mathrm{TP}<1$ \\
\hline 6 & Banyuasri & 0,18 & $\mathrm{TP}<1$ \\
\hline 7 & Banjar Tegal & 0,68 & $\mathrm{TP}<1$ \\
\hline 8 & Paket Agung & 0,13 & TP $<1$ \\
\hline 9 & Beratan & 0,07 & $\mathrm{TP}<1$ \\
\hline 10 & Liligundi & 0,02 & $\mathrm{TP}<1$ \\
\hline 11 & Kampung Singaraja & 0,08 & $\mathrm{TP}<1$ \\
\hline 12 & Kendran & 0,03 & TP $<1$ \\
\hline 13 & Astina & 0,35 & $\mathrm{TP}<1$ \\
\hline 14 & Banjar Jawa & 0,67 & TP $<1$ \\
\hline 15 & Banjar Bali & 0 & Nonpertanian \\
\hline 16 & Kampung Kajanan & 0 & Nonpertanian \\
\hline 17 & Kaliuntu & 0 & Nonpertanian \\
\hline
\end{tabular}




\begin{tabular}{lllc}
\hline $\mathbf{1 8}$ & Kampung Anyar & 0 & Nonpertanian \\
$\mathbf{1 9}$ & Kampung Bugis & 0 & Nonpertanian \\
$\mathbf{2 0}$ & Kampung Baru & 0 & Nonpertanian \\
$\mathbf{2 1}$ & Banyuning & 1,67 & TP $>1$ \\
$\mathbf{2 2}$ & Penarukan & 2,00 & TP $>1$ \\
$\mathbf{2 3}$ & Jineng Dalem & 0,27 & TP $<1$ \\
$\mathbf{2 4}$ & Penglatan & 2,76 & TP $<1$ \\
$\mathbf{2 5}$ & Petandakan & 0,45 & TP $<1$ \\
$\mathbf{2 6}$ & Sari Mekar & 0,69 & TP $<1$ \\
$\mathbf{2 7}$ & Naga Sepaha & 0,29 & TP $<1$ \\
$\mathbf{2 8}$ & Alasn Sangker & 0,33 & TP $<1$ \\
$\mathbf{2 9}$ & Poh Bergong & 0,85 & TP $<1$ \\
Kecamatan Buleleng & 0,54 & TP $<1$ \\
\hline
\end{tabular}

Sumber: Analisa Data Sekunder, 2017

Perhitungan tekanan penduduk terhadap lahan pertanian dengan menggunakan Model I juga digunakan Rina Dwi Ariani (2012) dalam penelitiannya yang berjudul "Tekanan Penduduk Terhadap Lahan Pertanian Di Kawasan Pertanian (Kasus Kecamatan Minggir dan Moyudan)". Hasil perhitungan tekanan penduduk di Kecamatan Buleleng menunjukkan bahwa Kecamatan Buleleng memiliki nilai TP kurang dari 1, berarti lahan di kecamatan Buleleng masih mampu memenuhi kebutuhan hidup penduduknya. Terdapat beberapa wilayah di Kecamatan Buleleng yang memiliki nilai $\mathrm{Tp}$ lebih dari 1 yaitu Tukad Mungga, Banyuning, Penarukan, Penglatan. Apabila ditinjau dari variabelvariabel yang mempengaruhi tekanan penduduk terdapat beberapa faktor yang mempengaruhi terjadinya tekanan penduduk di Desa/Kelurahan tersebut, faktor yang dimaksudkan adalah sebagai berikut: (1)Tingginya laju pertumbuhan penduduk yang menyebabkan contohnya Banyuning, (2) Keterbatasan lahan pertanian yang berpengaruh terhadap pendapatan dan tingkat perekonomian masyarakat, (3) Pengelolaan lahan yang tidak maksimal sehingga produksinya sedikit contohnya Tukad Mungga, Penarukan, Penglatan,(4) Rencana tata ruang wilayah belum dilaksanakan secara benar dan bertanggungjawab.

Beberapa wilayah di Kecamatan Buleleng ada yang merupakan kawasan nonpertanian yaitu Banjar Bali, Kampung Kajanan, Kaliuntu, Kampung Baru, Kampung anyar, dan Kampung Bugis.
Dearah ini dikatogikan kawasan nonpertanian karena penduduknya tidak ada yang berprofesi sebagai petani dan tidak ada lahan pertanian. Hasil perhitungan tekanan penduduk terhadap lahan di Kecamatan Buleleng memiliki perbedaan dengan hasil penelitian tekanan penduduk terhadap lahan pertanian di Kecamatan Minggir dan Moyudan yang di lakukan oleh Rina Dwi Ariani (2012) yang menyatakan dikedua Kecamatan tersebut tidak terjadi Tekanan penduduk terhadap lahan pertanian. Perbedaan hasil penelitian ini dikarenakan meskipun Kecamatan Minggir dan Moyudan mengalami alih fungsi lahan sama halnya seperti Kecamatan Buleleng namun jumlah penduduk di Kecamatan Minggir dan Moyudan mengalami penurunan.

\section{Daya Dukung Lahan Pertanian Di Kecamatan Buleleng.}

Pengukuran daya dukung lahan menurut Rahardja (1997) yang menggunakan variabel konsumsi fisik minimum, produksi beras, luas panen padi, dan jumlah penduduk, maka diketahui nilai daya dunking lahan di Kecamatan Buleleng. KMF ditentukan sebesar 151,2 kg/orang atau nilai rata-rata indeks KMF pekerja dan keluarganya selama satu bulan. Produksi per satuan luas dan waktu (yield) dipergunakan rata-rata produksi padi perhektar, yang dikonversikan menjadi beras. Besarnya angka konversi padi ke beras menggunakan criteria BPS yaitu sebesar $68 \%$. Luas panen tanaman padi dalam satu tahun dicari dengan 
menjumlahkan luas panen sawah dua musim dan satu musim dalam ha. Jumlah penduduk dalam suatu wilayah dihitung jumlah penduduk dalam akhir tahun. Nilai daya dukung lahan di Kecamatan Buleleng dapat dilihat pada tabel berikut:

Tabel 2. Katagori Daya Dukung Lahan Di Kecamatan Buleleng

\begin{tabular}{llcc}
\hline No & \multicolumn{1}{c}{ Desa/Kelurahan } & DDL & Katagori \\
\hline $\mathbf{( 1 )}$ & Kalibukbuk & $\mathbf{( 3 )}$ & $(\mathbf{4})$ \\
$\mathbf{1}$ & Kanturan & 0,21 & $<1$ \\
$\mathbf{2}$ & Tukad Mungga & 0,20 & $<1$ \\
$\mathbf{3}$ & Pemaron & 0,79 & $<1$ \\
$\mathbf{4}$ & Bakti Seraga & 0,19 & $<1$ \\
$\mathbf{5}$ & 0,73 & $<1$ \\
$\mathbf{6}$ & Banyuasri & 0,32 & $<1$ \\
$\mathbf{7}$ & Banjar Tegal & 0,02 & $<1$ \\
$\mathbf{8}$ & Paket Agung & 0.54 & $<1$ \\
$\mathbf{9}$ & Beratan & 0 & Nonpertanian \\
$\mathbf{1 0}$ & Liligundi & 0,12 & $<1$ \\
$\mathbf{1 1}$ & Kampung Singaraja & 0 & Nonpertanian \\
$\mathbf{1 2}$ & Kendran & 0 & Nonpertanian \\
$\mathbf{1 3}$ & Astina & 0 & Nonpertanian \\
$\mathbf{1 4}$ & Banjar Jawa & 0 & Nonpertanian \\
$\mathbf{1 5}$ & Banjar Bali & 0 & Nonpertanian \\
$\mathbf{1 6}$ & Kampung Kajanan & 0 & Nonpertanian \\
$\mathbf{1 7}$ & Kaliuntu & 0 & Nonpertanian \\
$\mathbf{1 8}$ & Kampung Anyar & 0 & Nonpertanian \\
$\mathbf{1 9}$ & Kampung Bugis & 0 & Nonpertanian \\
& Kampung Baru & & \\
$\mathbf{2 0}$ & Banyuning & 0 & Nonpertanian \\
$\mathbf{2 1}$ & Penarukan & 0,68 & $<1$ \\
$\mathbf{2 2}$ & Jineng Dalem & 0,92 & $<1$ \\
$\mathbf{2 3}$ & Penglatan & 1.39 & $>1$ \\
$\mathbf{2 4}$ & Petandakan & 0,93 & $<1$ \\
$\mathbf{2 6}$ & Sari Mekar & 2,13 & $>1$ \\
$\mathbf{2 7}$ & Naga Sepaha & 1,13 & $>1$ \\
$\mathbf{2 8}$ & Alasn Sangker & 0,88 & $<1$ \\
$\mathbf{2 9}$ & Poh Bergong & 1,62 & $>1$ \\
$\mathbf{K e}$ & 1,44 & $>1$ \\
\hline & & 0,49 & $<1$ \\
\hline
\end{tabular}

Sumber: Analisa Data Sekunder, 2017

Rumus pengukuran yang sama juga digunakan Arie Agustina Fitriani (2003) yang berjudul "Analisis Daya Dukung Lahan Pertanian Dan Tekanan Penduduk Studi Kasus Jawa Timur)". Daya dukung lahan pertanian merupakan indikator yang sederhana, menunjukkan suatu wilayah dapat swasembada yang diukur dari ketersedian bahan pangan khusus beras. Berdasarkan rumus DDL dengan katagori jika ni DDL>1 maka wilayah tersebut mampu swasembada pangan jika nilai DDL $<1$ maka wilayah tersebut tidak mampu swasembada pangan dalam arti jumlah penduduk telah jumlah penduduk optimal DDL $=1$ maka wilayah tersebut memiliki daya dukung yang optimal. Kecamatan dilihat secara keselurahan memliki nilai DDL 0,49 itu berarti daya dukung di Kecamatan Buleleng tidak mampu swasembada pangan dalam arti jumlah penduduk telah jumlah penduduk optimal. Terdapat beberapa Desa/Kelurahan di Kecamatan Buleleng yang mampu swasembada pangan yaitu Jineng dalem, Petandakan, Sari Mekar, Poh Bergong, hal 
ini dikarenakan daerah-daerah tersebut memiliki luas lahan sawah yang luas dan jumlah penduduk yang sedikit. Hasil penelitian ini berbeda dengan hasil penelitian Arie Agustina Fitriani (2003) yang menyatakan bahwa Provinsi Jawa Timur masih mampu swasembada pangan, hal ini dikarena Provinsi Jawa Timur memiliki produksi beras yang maksimal sehingga mampu memenuhi kebutuhan hidup penduduknya.

\section{SIMPULAN DAN SARAN}

Tekanan penduduk terhadap lahan pertanian di Kecamatan Buleleng dikatogorikan menjadi 2 TP $>1$ tekanan penduduk tinggi, TP $<1$ Tekanan penduduk rendah. Secara keseluruhan di Kecamatan Buleleng tekanan penduduknya masih rendah karena nilai TPnya 0,54 yaitu kurang dari 1 berarti Kecamatan Buleleng masih mampu memenuhi kebutuhan hidup penduduknya. Terdapat beberapa desa/kelurahan di Kecamatan Buleleng yang tekanan pennduduknya tinggi yaitu Tukad Mungga, Banyuning, Penarukan, Penglatan.

Daya Dukung lahan di Kecamatan Buleleng dikatogikan menjadi 2 yaitu nilai DDL $>1$ wilayah tersebut mampu swasembada pangan, $\mathrm{DDL}<1$ wilayah tersebut tidak mampu swasembada pangan. Secara keseluruahan Kecamatan Buleleng tidak mampu swasembada pangan karena nilai $\mathrm{DDL}<1$ yaitu 0,49. Terdapat beberapa Desa/Kelurahan di Kecamatan Buleleng yang mampu swasembada pangan yaitu Jineng dalem, Petandakan, Sari Mekar, Poh Bergong, hal ini dikarenakan daerah-daerah tersebut memiliki luas lahan sawah yang luas dan jumlah penduduk yang sedikit.

Berdasarkan pada hasil penelitian, pembahasan, dan simpulan, maka dapat diajukan beberapa saran sebagai berikut: Bagi masyarakat, sebagai pengelola lahan pertanian diharapkan mampu meningkatkatkan kesadaran akan pentingnya memanfaatkan lahan secara arif dan bijaksana mengingat kecamatan buleleng memiliki potensi pertanian namun Kecamatan Buleleng tidak mampu swasembbada pangan. Bagi pemerintahan, sebagai penentu kebijakan diharapkan mampu menetapkan strategi kebijakan berupa perencanaan tata ruang yang tepat dan strategi pengelolaan lahan sehingga produksi pertanian semakin meningkat dan mampu swasembada pangan.

\section{DAFTAR PUSTAKA}

Ariani, Rina Dwi. 2012. Tekanan Penduduk Terhadap Lahan Pertanian Dikawasan Petanian (Kasus Kecamatan Minggir Dan Moyudan. Skripsi tidak diterbitkan. Surabaya: Unversitas Negeri Surabaya

BPS Kecamatan Buleleng. 2016. Kecamatan Buleleng Dalam Angka 2016. Dapat di Unduh dari: http://bulelengkab. Bps.go.id. (diunduh 10 desember 2016).

Fitriani, Ari Agustia. 2005. Analisis Daya Dukung Lahan Pertanian Dan Tekanan Penduduk. Skripsi tidak diterbitkan. Tersedia pada: https://eprints.uns.ac.id/7505/1/68 $892206200906221 . p d f$. Di unduh 8 november 2016.

Mantra, Ida Bagus. 2003. Demografi Umum. Yogyakarta: Pustaka Pelajar.

Rahardja, Mugi. 1997. Pengantar Ekonomi Sumber Daya Alam. Fakultas Ekonomi UNS Surakarta :UNS Press

Sartohadi J, P. F. (2008). "Evaluasi potensi degradasi lahan dengan menggunakan analisa kemampuan lahan dan tekanan penduduk terhadap lahan pertanian di Kecamatan Kokap Kabupaten Kulon Progo". Forum Geografi. Vol. 2 (Halaman 11-12).

Suratha, I Ketut.2015. Krisis Petani Berdampak Pada Ketahanan Pangan Di Indonesia.E-Journal Media Komunikasi Geografi. Vol 16 No 1 (Halaman 67)

Sonny, Lazio. 2013. pengertian daya dukung lahan serta faktor-faktor 
penentu dan faktor-faktor

penghambat. Tersedia pada:

http://sonnylazio.blogspot.co.id/20

13/01/pengertian-daya-dukung-

lahan-serta.html. .Diakses 01

November

2016 
